\title{
The Temperature Response and Aggressiveness of Peyronellaea pinodes Isolates Originating from Wild and Domesticated Pisum sp. in Israel
}

\author{
M. Golani, S. Abbo, A. Sherman, O. Frenkel, and D. Shtienberg
}

First, fourth, and fifth authors: Department of Plant Pathology, Volcani Center, Agricultural Research Organization, Bet-Dagan 50250, Israel; first and second authors: The Robert H Smith Faculty of Agriculture, Food and Environment, The Levi Eshkol School of Agriculture, The Hebrew University of Jerusalem, Rehovot 7610001, Israel; and third author: Genomics Department, Volcani Center, Agricultural Research Organization, Bet-Dagan 50250, Israel.

Accepted for publication 28 March 2016.

\begin{abstract}
Golani, M., Abbo, S., Sherman, A., Frenkel, O., and Shtienberg, D. 2016. The temperature response and aggressiveness of Peyronellaea pinodes isolates originating from wild and domesticated Pisum sp. in Israel. Phytopathology 106:824-832.

Domesticated pea fields are grown in relatively close proximity to wild pea species in Israel. Despite the major role attributed to ascochyta blight in causing yield losses in domesticated pea, very limited information is available on the pathogens prevailing in natural ecosystems. The objectives of this study were (i) to identify the species causing ascochyta blight symptoms on leaves, stems, and petioles of domesticated pea and wild Pisum plants in Israel, and (ii) to quantify the temperature response(s) and

sativum, 11 from Pisum fulvum, and four from Pisum elatius. All isolates were identified as Peyronellaea pinodes. Spore germination and mycelial growth took place over a wide range of temperatures, the lower and upper cardinal temperatures being 2 to 9 and 33 to $38^{\circ} \mathrm{C}$, respectively; the optimal temperatures ranged from 22 to $26^{\circ} \mathrm{C}$. At an optimal temperature, disease severity was significantly higher for plants maintained under moist conditions for $24 \mathrm{~h}$ postinoculation than for those exposed to humidity for 5 or $10 \mathrm{~h}$. Analyses of the data revealed that temperature responses, spore germination rates, and aggressiveness of isolates sampled from domesticated pea plants did not differ from those of isolates sampled from adjacent or distant wild populations. Host specificity was not observed. These observations suggest that Israel may be inhabited by a single metapopulation of $P$. pinodes.
\end{abstract} aggressiveness of such pathogens originating from Pisum plants growing in sympatric and allopatric contexts. Eighteen fungal isolates were examined and identified; three of them were sampled from Pisum

Peyronellaea pinodes (Berk. \& A. Bloxam) Aveskamp, Gruyter \& Verkley (Aveskamp et al. 2010) [syn. Didymella pinodes (Berk. \& Blox.) Vestergr; Mycosphaerella pinodes] is one of four fungal pathogens that cause ascochyta blight in pea (Pisum sativum L.) crops worldwide (Jones 1927; Wallen 1965). The other pathogens causing ascochyta blight in pea are Phoma medicaginis var. pinodella (L.K. Jones) Morgan-Jones \& K.B. Burch., Ascochyta pisi Lib (Chilvers et al. 2009; Onfroy et al. 1999; Skoglund et al. 2011), and the recently described Phoma koolunga (Davidson et al. 2009). Peyronellaea pinodes is considered to be the major pathogen causing yield losses in commercial pea fields (Bretag et al. 2006; Khan et al. 2013; Tivoli and Banniza 2007). Losses were estimated to range from 10 to $20 \%$, but in some trials, they may exceed $50 \%$ (Khan et al. 2013; Xue and Warkentin 2001). The aim of many studies has been to determine survival of the fungi responsible for the disease from year to year, how the disease becomes established in new crops, and what conditions favor disease development; their results were used to develop improved disease management strategies. Crop losses from the disease can be minimized by reducing the amount of inoculum, increasing the disease resistance of pea varieties, and modifying cultural practices (Bretag et al. 2006; Khan et al. 2013; Tivoli and Banniza 2007).

Corresponding author: D. Shtienberg; E-mail address: danish@volcani.agri.gov.il

*The $\boldsymbol{e}$-Xtra logo stands for "electronic extra" and indicates that one supplementary table is published online.

http://dx.doi.org/10.1094/PHYTO-11-15-0306-R

(C) 2016 The American Phytopathological Society
Additional keywords: Didymella pinodes, Mycosphaerella pinodes, temperature adaptation.
In many traditional pea-growing areas, cultivated fields can be found relatively close to wild pea species (Abbo et al. 2007; BenZe'ev and Zohary 1973; Ladizinsky and Abbo 2015; Le May et al. 2014). These include wild Pisum elatius, a member of plant communities in Spain, on Mediterranean islands (e.g., Mallorca, Sardinia, Cyprus), and throughout southern France, Italy, the Balkans, and eastern Mediterranean countries. The distribution of this wild taxon also extends to temperate Central European regions such as Hungary, Bulgaria, and the Crimean peninsula, and from the Middle East through the Trans-Caucasus toward Turkmenistan and, possibly, into other Central Asian regions (Ladizinsky and Abbo 2015). Pisum fulvum is an eastern Mediterranean plant community member, documented mainly in Israel, Jordan, Lebanon, Syria, and Turkey. Wild Pisum humile is known in Turkey and Syria, and its distribution overlaps that of Pisum fulvum in certain locations in Israel, where they often occur together in the same microhabitats (Abbo et al. 2008).

Coevolution of plants and their pathogens occurs both in natural ecosystems and in cultivated fields (Burdon 1987; Harlan 1976; Stukenbrock and McDonald 2008). Because centers of origin of crop plants are considered also to be locales of origin of some of their pathogens (Leppik 1970), sympatric occurrence of domesticated crops and their wild relatives are key for improved understanding of pathogen biology (Abbo et al. 2007; Gladieux et al. 2011; Leroy et al. 2014). In contrast to cereals, pathogens affecting legumes on the boundaries between wild and agricultural ecosystems were hardly studied. Indeed, Frenkel et al. (2008; 2010) and Ozkilinc et al. (2010; 2011) have studied the sympatric pathosystem of wild and domesticated chickpea and their fungal pathogen Didymella rabiei in Israel and Turkey. Assessment of the ecological requirements of pathogen isolates sampled from wild and domesticated chickpea and simple sequence repeat variation provided evidence for ecological 
and genetic divergence of pathogen populations from the two (wild versus domesticated chickpea fields) demes (Frenkel et al. 2010; Özkilinc et al. 2010; 2011). Evidence for cryptic speciation processes has been obtained from hybridization experiments with selected isolates from the two demes (Frenkel et al. 2010). The ecological and genetic divergence of the pathogen was attributed to the ancient shift of chickpea from a winter annual into a spring-sown crop (Abbo et al. 2003; Frenkel et al. 2010).

Peyronellaea pinodes can infect several wild and domesticated legume species (Fondevilla et al. 2005; Habibi et al. 2016; Le May et al. 2014). Interestingly enough, despite the major role attributed to ascochyta blight in causing yield losses in domesticated pea and the occurrence of wild Pisum spp. across vast geographic areas in which domesticated pea is an important crop, very limited information is available on the pathogens prevailing in natural ecosystems. Only two anecdotal reports exist; one, from Israel, pointed out that ascochyta blight does not assume epidemic proportions in wild pea populations (Dinoor 1974), and the other, from Bulgaria, described the isolation of $P$. pinodes from Pisum elatius (Kaiser et al. 1998). However, no data on the occurrence of ascochyta blight epidemics in wild pea populations or on the potential for inoculum originating from wild Pisum plants to infect domesticated pea crops were published. Furthermore, and to the best of our knowledge, except for one study that compared winter and spring populations of domesticated pea in France (Le May et al. 2012), there has been no reported study that compared pathogen biology from two, presumably $P$. pinodes demes, i.e., natural ecosystems and cultivated fields, with respect to ecological requirements or genetic affinities.

Identification of the ascochyta pathogens of wild Pisum spp. and quantification of their ecological requirements and aggressiveness, as compared with those of pathogen strains infecting domesticated pea, in allopatry and in sympatry, are fundamental for understanding the evolution of this economically important pathogen. From an agronomic perspective, this information is important for assessing the potential of wild pea populations to provide a source of primary inoculum for domesticated pea fields as well as for resistance breeding (Warkentin et al. 2015). Since no major shifts in the growing season of pea have occurred since domestication, we hypothesize that the temperature responses of the pathogens causing ascochyta blight originating from domesticated pea plants and their aggressiveness do not differ from that of isolates originating from wild Pisum plants growing in sympatry. Our second hypothesis is that the temperature responses and the aggressiveness of the pathogens isolated from Pisum plants growing in different locations under dissimilar conditions differ significantly. The following objectives were conceived to test these hypotheses: (i) to identify the pathogenic species causing ascochyta blight symptoms on leaves, stems, and petioles of domesticated pea and wild Pisum plants in Israel; (ii) to quantify the temperature responses and aggressiveness of the pathogens that cause ascochyta blight and that originated from Pisum plants growing in sympatric contexts; and (iii) to quantify the temperature responses and aggressiveness of the pathogens causing ascochyta blight that originated from wild Pisum plants growing in allopatric populations.

\section{MATERIALS AND METHODS}

Collection of pathogen isolates. Commercial processing-pea fields (Pisum sativum; cv. Karina) in the Bet-She' an valley in Israel were inspected visually during the 2005-2006 to 2007-2008 seasons, and plant parts (leaves, stems, and petioles) exhibiting the typical ascochyta blight symptoms (Tivoli and Banniza 2007) were randomly sampled. Wild Pisum populations from adjacent (sympatric) rangeland were surveyed and plants with disease symptoms were sampled. In parallel, symptomatic plant parts were sampled from wild Pisum populations from eastern Galilee (A'mud Creek), western Galilee (Kziv and Gaa'ton Creeks), western Samaria (I'ron Creek), and the southern Judean Foothills (Lakhish); these populations are allopatric to the ones growing in the Bet-She'an sites (Table 1).

Symptomatic sections of the sampled plant parts were inspected under a binocular microscope $($ at $\times 20)$ for the presence of pycnidia. Sections bearing pycnidia were disinfested in a domestic bleach solution (sodium hypochlorite at $10 \mathrm{~g}$ per liter) for $1 \mathrm{~min}$, were washed once with sterile water, and were dried on sterile filter paper. The samples were then placed on $9-\mathrm{cm}$ petri dishes with potato dextrose agar (PDA) (Difco) and were incubated in a growth chamber at $22 \pm 1{ }^{\circ} \mathrm{C}$ for 10 days, under a cycle of alternating $12 \mathrm{~h}$ of near UV light and $12 \mathrm{~h}$ of darkness. Then, a disk was taken aseptically from the margin of the growing colony and was transferred to a new petri dish. After 1 week, 5-mm disks bearing pycnidia were sampled, were dipped in $1 \mathrm{ml}$ of distilled water, and were agitated. Subsamples of $120 \mu \mathrm{l}$ were evenly distributed on another set of petri dishes and were incubated at $22^{\circ} \mathrm{C}$. Single-spore cultures were then prepared and were used for identification and further experimentation.

Identification of one or more pathogens causing ascochyta blight symptoms on wild and domesticated Pisum plants. A total of 18 isolates originating from wild and domesticated Pisum plants were examined and identified. First, each isolate was identified morphologically by comparing conidial size, number of conidial cells, and formation of chlamidiospores with the previous descriptions of Jones (1927) and Peever et al. (2007). Then, isolates were identified by using DNA polymorphism data as follows.

Liquid cultures of the 18 isolates were initiated from singleconidial isolates in 250-ml flasks containing $100 \mathrm{ml}$ of 2-YEG medium (yeast extract at $2 \mathrm{~g}$ per liter and glucose at $10 \mathrm{~g}$ per liter), as described by Frenkel et al. (2010). Flasks were incubated for 7 days on a rotary shaker at $22^{\circ} \mathrm{C}$. Mycelium was vacuum-filtered through Miracloth, was lyophilized, and was stored at $-80^{\circ} \mathrm{C}$. DNA was extracted from ground mycelium with the Master Pure yeast DNA purification kit (Epicenter Biotechnologies), and the DNA concentration was determined using an ND-1000 spectrophotometer (NanoDrop Technologies) and was adjusted to $20 \mathrm{ng} / \mu \mathrm{l}$ for polymerase chain reaction (PCR). In order to confirm the morphological classification of the fungus as $P$. pinodes, we amplified and sequenced part of the rDNA internal transcribed spacer (ITS) region. Primers ITS1 and ITS4 were used to amplify the ITS1-5.8S-ITS2 region according to White et al. (1990). The ITS sequences of the 18 selected isolates were compared with reference isolates of the three species that form the

TABLE 1. Information on the origin of the Peyronellaea pinodes isolates used in this study

\begin{tabular}{|c|c|c|c|c|}
\hline \multirow[b]{2}{*}{ Original host plant } & \multicolumn{3}{|c|}{ Site of sampling } & \multirow[b]{2}{*}{ Isolate code } \\
\hline & Location & Latitude & Longitude & \\
\hline \multirow[t]{2}{*}{ Pisum sativum } & Bet-She'an valley & $32^{\circ} 29^{\prime} 02$ & $35^{\circ} 27^{\prime} 48$ & Ps-BS1; Ps-BS2; Ps-BS3 \\
\hline & Mt. Gilboa & $32^{\circ} 33^{\prime} 08$ & $35^{\circ} 20^{\prime} 28$ & Ps-MG1 \\
\hline \multirow{3}{*}{ Pisum fulvum } & Kziv Creek & $32^{\circ} 02^{\prime} 35$ & $35^{\circ} 11^{\prime} 06$ & Pf-KV1 \\
\hline & A'mud Creek & $32^{\circ} 52^{\prime} 02$ & $35^{\circ} 30^{\prime} 14$ & Pf-AC1; Pf-AC2; Pf-AC3 \\
\hline & I'ron Creek & $32^{\circ} 32^{\prime} 39$ & $35^{\circ} 09^{\prime} 42$ & Pf-IC1 \\
\hline
\end{tabular}


ascochyta complex. The confirmed Ascochyta pisi, $P$. pinodes, and Phoma pinodella reference isolates were imported from the Centraalbureau voor Schimmeculture Collection in Utrecht, the Netherlands.

As ITS regions seldom provide sufficient information beneath the species level, portions of the gene coding for the protein glyceraldehyde-3-phosphate dehydrogenase (G3PD) also were sequenced for all 18 studied isolates. These regions were used previously to estimate the phylogeny among Ascochyta spp. and were proven to be informative at or below the species level (Peever et al. 2007). A portion of the G3PD gene was amplified with each of the primers gpd- 1 and gpd- 2 at $0.4 \mathrm{mM}$ (Berbee et al. 1999). The cycling conditions were $94^{\circ} \mathrm{C}$ for $3 \mathrm{~min}$, followed by 30 cycles of $94^{\circ} \mathrm{C}$ for $30 \mathrm{~s}, 60^{\circ} \mathrm{C}$ for $30 \mathrm{~s}$, and $72^{\circ} \mathrm{C}$ for $1 \mathrm{~min}$, followed by $10 \mathrm{~min}$ at $72^{\circ} \mathrm{C}$, as described by Peever et al. (2007). The PCR products were detected on $1 \%$ agarose gel and were purified with ExoSap (Amersham) according to the manufacturer's protocol. PCR products were sequenced by Macrogen, using an ABI PRISM 3100 DNA sequencer. Raw sequences were edited using Vector NTI (Invitrogen) and were aligned using DNAMAN software (Lynnon BioSoft). Nucleotide sequences were deposited in GenBank under the following accession numbers, as described later: for G3PD from Pisum elatius (KT361628) and the ITS1-5.8S-ITS2 region from Pisum fulvum (KT428767).

Temperature response of $\boldsymbol{P}$. pinodes isolates. In vitro tests were performed to evaluate the temperature responses of $P$. pinodes isolates sampled from wild and domesticated Pisum species, growing in sympatric and allopatric populations. For the mycelial growth experiments, 8-mm agar disks from the margins of 14-day-old colonies were placed in the center of $90-\mathrm{mm}$ agar plates containing PDA. The plates were maintained at temperatures of 5, 10, 15, 20, 25,30 , and $35 \pm 1^{\circ} \mathrm{C}$ in growth chambers. After 14 days, colony size was measured in two perpendicular directions and the colony area was calculated. There were four replicates (petri dishes) per treatment $(P$. pinodes isolate $\times$ temperature) and the experiments were repeated once. Third-order polynomial regressions were computed for each treatment, the dependent variable $(Y)$ being colony area (in square centimeters) and the independent variables $\left(X, X^{2}, X^{3}\right)$ being temperature (in degrees Celsius). Solving the equations for $Y=0$ enabled estimation of the lower and upper cardinal temperatures for each isolate. Optimal temperatures were estimated after calculating the first derivatives of the regression equations.

For the spore germination experiments, pycnidiospores were produced from 7-day-old colonies growing on PDA and were maintained in a growth chamber at $22 \pm 1{ }^{\circ} \mathrm{C}$ under an alternating cycle of $12 \mathrm{~h}$ of near UV light and $12 \mathrm{~h}$ of darkness. Tubes containing $2 \mathrm{ml}$ of spore suspension $\left(5 \times 10^{5}\right.$ spores per milliliter $)$ in $0.1 \%$ molten agar were incubated for $24 \mathrm{~h}$ at $5,10,15,20,25,30$, or $35 \pm 1^{\circ} \mathrm{C}$. Then, $25-\mu 1$ subsamples were taken and transferred to minitubes. Cotton-blue dye $(25 \mu \mathrm{l})$ was added to each minitube to stop the germination process and stain the spores. Spore germination was determined under a light microscope, at magnification of $\times 200$. Fifty spores were observed per replicate; they were considered as germinating if the length of the germ tube was greater than the width of the spore. Germination rate, as percentage, was calculated based on the number of germinating spores in each replicate. There were three replicates (minitubes) per treatment and the experiments were repeated once. The lower and upper cardinal and the optimal temperatures for spore germination for each isolate were computed as described above.

For determining the time required for spore germination, the experimental procedures were, in general, similar to those described above, with minor differences. The differences were (i) the tubes were maintained at 10 or $20^{\circ} \mathrm{C}$, (ii) samples were taken and transferred to minitubes, and cotton-blue dye was added after $0,2,4,6,8$, or $10 \mathrm{~h}$, and (iii) data were analyzed using sigmoid regression equations in which the dependent variable $(Y)$ was spore germination rate (percentage) and the independent variable $(X)$ was time in hours.
For each sampling time, analysis of variance (ANOVA) was used to evaluate differences in germination rates between the tested $P$. pinodes isolates.

Aggressiveness of $\boldsymbol{P}$. pinodes isolates. In vivo tests were performed to evaluate the aggressiveness of $P$. pinodes isolates sampled from wild and domesticated Pisum species growing in sympatric and allopatric populations. Aggressiveness was determined against one domesticated cultivar (Pisum sativum cv. Karina) and two wild lines (Pisum fulvum and Pisum elatius, originated from Upper Galilee). Plants were grown, two plants per pot, in 1-liter pots filled with a 1:1 mixture of tuff and peat. The plants were maintained in a growth chamber at $22 \pm 1^{\circ} \mathrm{C}$ under a cycle of alternating $12 \mathrm{~h}$ of light and $12 \mathrm{~h}$ of darkness; they were irrigated and fertilized as needed. Two weeks after planting, when the plants carried three or four true leaves, they were inoculated with spore suspensions of the tested $P$. pinodes isolates. Spore suspensions $\left(5 \times 10^{5}\right.$ spores per milliliter $)$ were prepared as described above and Tween $80(0.1 \%)$ was added to the solution before inoculation. The plants were sprayed to runoff by means of an air-pressure hand sprayer and, then, were covered with two layers of plastic bags to preserve leaf wetness and were returned to the growth chamber.

There were two sets of experiments. The aim of the first set (two repeated experiments, 1 and 2) was to evaluate the aggressiveness of P. pinodes isolates originating from Pisum sativum or Pisum fulvum growing in sympatry. In these experiments, both Pisum sativum and Pisum fulvum were inoculated and inoculated plants were kept moist for 5, 10, or $24 \mathrm{~h}$ after inoculation. Plants sprayed with water and kept under comparable conditions served as untreated controls. There were five replicates (pots) per treatment. Disease severity, expressed as the proportion of leaf area exhibiting the typical ascochyta blight symptoms, was assessed visually by the same individual every two to three days, until 15 days after inoculation. Disease severity records throughout the experiment were integrated by calculating the relative area under the disease-progress curve (RAUDPC), according to Shaner and Finney (1977). The following linear hierarchical-factorial ANOVA model was used for data analysis.

$$
\begin{aligned}
\mathrm{Y}_{\mathrm{ijklm}}= & \mu+\mathrm{OH}_{\mathrm{i}}+\mathrm{CH}_{\mathrm{j}}+\mathrm{I}_{\mathrm{k}}\left[\mathrm{OH}_{\mathrm{i}}\right]+\mathrm{W}_{1}+\mathrm{OH} \times \mathrm{CH}_{\mathrm{ij}}+\mathrm{OH}_{\mathrm{i}} \times \mathrm{W}_{\mathrm{il}} \\
& +\mathrm{I}_{\mathrm{k}}\left[\mathrm{OH}_{\mathrm{i}}\right] \times \mathrm{CH}_{\mathrm{j}}+\mathrm{I}_{\mathrm{k}}\left[\mathrm{OH}_{\mathrm{i}}\right] \times \mathrm{W}_{1}+\mathrm{CH} \times \mathrm{W}_{\mathrm{jl}} \\
& +\mathrm{OH} \times \mathrm{CH} \times \mathrm{W}_{\mathrm{ijl}}+\mathrm{I}_{\mathrm{k}}\left[\mathrm{OH}_{\mathrm{i}}\right] \times \mathrm{CH} \times \mathrm{W}_{\mathrm{jl}}+\varepsilon_{\mathrm{ijklm}}
\end{aligned}
$$

where $Y_{\mathrm{ijklm}}$ is final disease severity records (arcsin transformed) or RAUDPC value, $\mu=$ overall mean, $\mathrm{OH}_{\mathrm{i}}=$ original host plant (fixed effect); $\mathrm{CH}_{\mathrm{j}}=$ challenged host species (fixed effect); $\mathrm{I}_{\mathrm{k}}\left[\mathrm{OH}_{\mathrm{i}}\right]=$ Isolate within host (random effect); $\mathrm{W}_{1}=$ wetness duration (fixed effect); $\varepsilon_{\mathrm{ijklm}}=$ random error. Plants sprayed with water and maintained under comparable conditions served as untreated controls. There were five replicates (pots) per treatment and the experiment was repeated once.

The aim of the second set of experiments (experiments 3 to 7) was to evaluate the aggressiveness of $P$. pinodes isolates originating from allopatric Pisum sativum, Pisum fulvum, or Pisum elatius populations. The five experiments shared the same design, but the Pisum species and the $P$. pinodes isolate used varied between the experiments, as described below. In these experiments Pisum sativum, Pisum fulvum, or Pisum elatius were grown in pots as described above and were inoculated with the tested $P$. pinodes isolates. After inoculation, the plants were kept wet for $24 \mathrm{~h}$. In these experiments, we used 16 isolates, three originated from Pisum sativum, nine from Pisum fulvum, and four from Pisum elatius. Isolate Ps-BS1 was used as a reference isolate in all experiments but experiment number 7 , in which isolate Ps-BS3 was used instead. Isolate Ps-BS3 was used in experiment number 7 because of a technical problem occurring at the time of inoculation of the plants. Isolates Ps-BS1 and Ps-BS3 were included in experiments that were not presented in the current report and their temperature response and aggressiveness were 
found comparable. Plants sprayed with water and kept under comparable conditions served as untreated controls. There were five replicates (pots) per treatment. Disease severity and RAUDPC values were recorded and calculated as described above, and data for each experiment were analyzed using one-way ANOVA. Treatment means were compared using Tukey's highly significant difference test at $P<0.05$.

\section{RESULTS}

Identification of one or more pathogens causing ascochyta blight symptoms on wild and domesticated Pisum plants. The symptoms observed on wild Pisum plants resembled, in general, those observed on plants growing in commercial fields. On the undersides of leaves, there were small purple spots without welldefined margins and well-defined, brown-black lesions. Complete collapse of leaves, stem lesions, and symptoms on pods, which were occasionally seen in domesticated peas, were rarely observed on wild plants. The morphological characteristics of the fungi isolated from symptomatic plant tissues from both wild and domesticated plants resembled those typical of $P$. pinodes. Alignment of the 487-bp ITS1-5.8S-ITS2 region from $P$. pinodes isolates showed $100 \%$ identity among all isolates from wild and domesticated hosts and from the reference isolates, and the ITS sequence was also $100 \%$ identical to that of Phoma pinodella (Aveskamp et al. 2008; Fatehi et al. 2003). In contrast, alignment with the A. pisi ITS1-5.8S-ITS2 region detected up to 14 single nucleotide polymorphisms (SNPs) and five gaps and, thereby, indicated that this was a useful means to distinguish A. pisi from the other species of the ascochyta complex. Partial G3PD sequencing yielded more substantial differences between the species of the pea ascochyta complex. Isolates from $P$. pinodes had six and two SNPs compared with Phoma pinodella and A. pisi, respectively. No SNPs were detected within or between the $P$. pinodes isolates from any of the three Pisum species, except for isolates Pf-AC2 and Pf-AC3, which originated from Pisum fulvum and had a single SNP at position 499. In light of the molecular tests, it was concluded that the ascochyta blight symptoms that developed on the sampled domesticated and wild Pisum plants resulted from $P$. pinodes infection.

Temperature responses and aggressiveness of $P$. pinodes isolates originating from Pisum plants growing in sympatry. Differences in temperature responses among $P$. pinodes isolates originating from Pisum sativum and Pisum fulvum plants growing in sympatry were insignificant. For the four tested isolates, the minimum cardinal temperature for mycelial growth and spore germination ranged from 5.5 to $9.0^{\circ} \mathrm{C}$ and 2.1 to $6.3^{\circ} \mathrm{C}$, respectively. The ranges for the optimal temperature were 22.8 to $25.5^{\circ} \mathrm{C}$ and 22.5 to $25.8^{\circ} \mathrm{C}$ and, for the upper cardinal temperature, 33.9 to $34.5^{\circ} \mathrm{C}$ and 34.0 to $37.7^{\circ} \mathrm{C}$, respectively (Fig. 1; Supplementary Table S1). The proportion of germinating spores increased with time. At $10^{\circ} \mathrm{C}, 40$ to $60 \%$ of the spores germinated after $10 \mathrm{~h}$, but at $20^{\circ} \mathrm{C}$, more than $50 \%$ of the spores germinated after 3 to $5 \mathrm{~h}$ and over $85 \%$ after $10 \mathrm{~h}$. According to the fitted regression lines, there was some degree of variability among the four tested isolates (Fig. 2). However, the isolates sampled from wild Pisum fulvum did not differ in their germination rates from those sampled from sympatric domesticated Pisum sativum plants.

To study the aggressiveness of the $P$. pinodes isolates originating from Pisum sativum and Pisum fulvum plants growing in sympatry, domesticated and wild pea plants were inoculated and maintained under three different postinfection wetness regimes. Records of
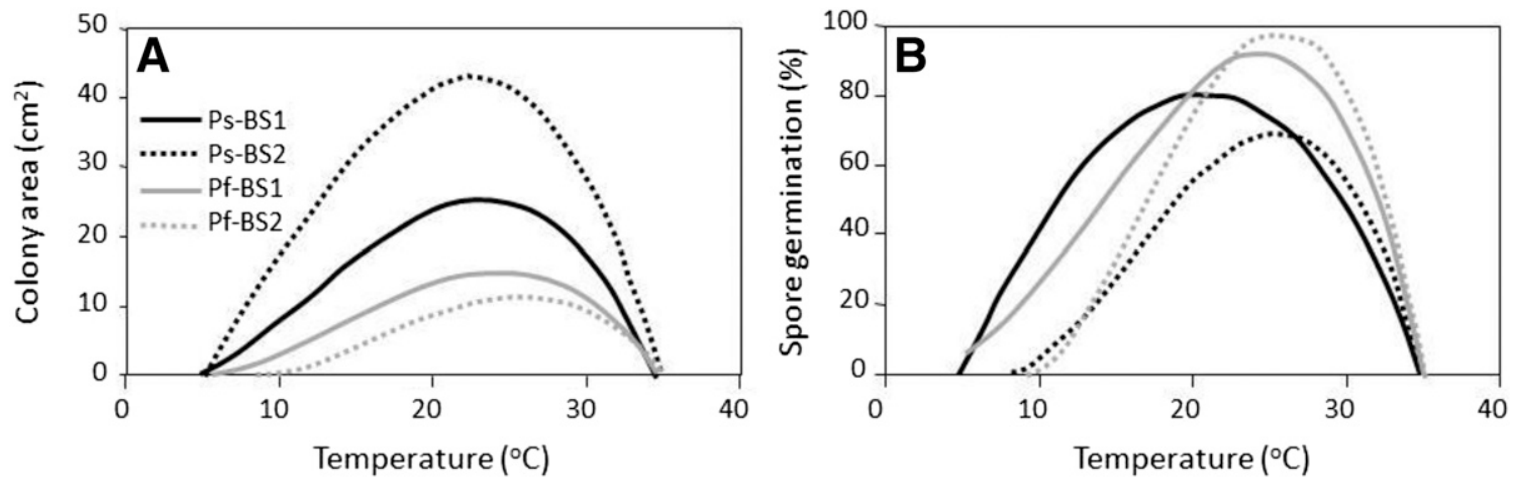

Fig. 1. Temperature responses of Peyronellaea pinodes isolates originating from domesticated (Pisum sativum [Ps]) and wild (Pisum fulvum [Pf]) Pisum plants, growing in sympatry in the Bet-She' an Valley. A, Mycelial growth and $\mathbf{B}$, spore germination. Regression equations are significant at $P<0.05$, with coefficients of determination $\left(\mathrm{R}^{2}\right)$ ranging from 0.41 to 0.93 . Data points are omitted to avoid crowding of the graphs.
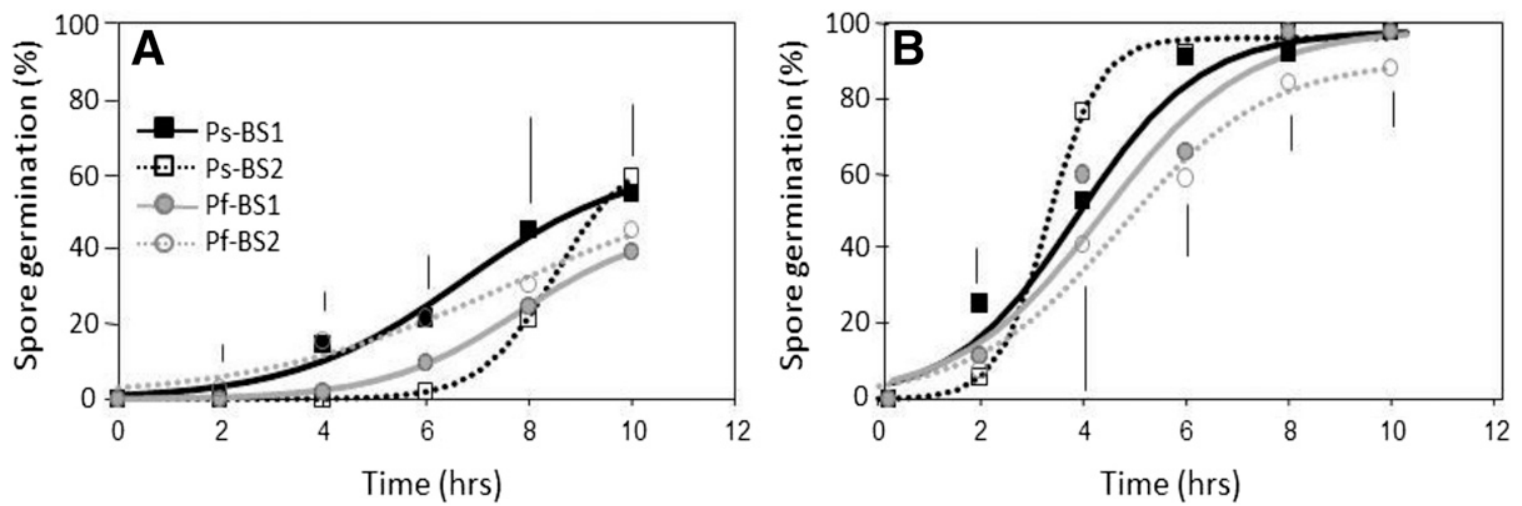

Fig. 2. Spore germination rates of Peyronellaea pinodes isolates originating from domesticated (Pisum sativum [Ps]) and wild (Pisum fulvum [Pf]) Pisum plants, growing in sympatry in the Bet-She'an Valley at $\mathbf{A}, 10^{\circ} \mathrm{C}$ and $\mathbf{B}, 20^{\circ} \mathrm{C}$. Regression equations are significant at $P<0.001$, with coefficients of determination ranging from 0.97 to 0.99 . Vertical lines represent the least significant difference between germination rates calculated for each temperature, as determined according to Tukey's highly significant difference test at $P<0.05$. 
final disease severity results for the two replicated experiments are presented in Figure 3, and the $P$ values for the ANOVA tests of final disease severity and RAUDPC values are presented in Table 2. Wetness duration had the strongest effect on the two aggressiveness parameters in both experiments. Likewise, a significant interaction effect of wetness duration $\times$ isolate (within host) was observed in both experiments (Table 2). The origin of the isolates (wild or domesticated pea) had no significant effect on the aggressiveness parameters (Table 2).

Temperature responses and aggressiveness of $P$. pinodes isolates originating from Pisum plants growing in allopatry. Differences among temperature responses of $P$. pinodes isolates originating from allopatric Pisum fulvum populations were minute and, furthermore, differences between these isolates and a representative isolate originated from Pisum sativum also were small. For the tested isolates the minimum cardinal temperatures for mycelial growth and spore germination ranged from 6.3 to $8.1^{\circ} \mathrm{C}$ and 4.4 to $7.1^{\circ} \mathrm{C}$, respectively. The ranges for the optimal temperatures were 23.4 to $25.6^{\circ} \mathrm{C}$ and 23.4 to $26.5^{\circ} \mathrm{C}$, respectively; for the upper cardinal temperatures, these ranges were 34.0 to $34.4^{\circ} \mathrm{C}$ and 34.7 to $35.9^{\circ} \mathrm{C}$, respectively (Fig. 4).

A similar pattern was observed in the rate of spore germination. At $10^{\circ} \mathrm{C}, 25$ to $75 \%$ of the spores germinated after $10 \mathrm{~h}$ but, at $20^{\circ} \mathrm{C}$, over $50 \%$ had germinated after 3 to $4 \mathrm{~h}$ and over $85 \%$ after $6 \mathrm{~h}$ (Fig. $5)$. There was variability among the tested isolates, but it could not be attributed to the diverse geographic origins of the isolates. For example, the sympatric isolates Ps-BS1 and Pf-BS1 (both from the Bet-She' an Valley) showed the higher and lower germination values at $10^{\circ} \mathrm{C}$, respectively. At the same time, the two allopatric isolates $\mathrm{Pf}-\mathrm{KC} 1$ and Pf-AC1, from western and eastern Galilee, respectively, showed identical germination pattern at $10^{\circ} \mathrm{C}$ and almost identical ones at $20^{\circ} \mathrm{C}$ (Fig. 5).

Further insight into possible effects of the host of origin of $P$. pinodes isolates and of their geographic origin (local ecology) on their aggressiveness patterns against wild and domesticated pea could be gained from data presented in Figure 6. Plants of domesticated pea as well as selected accessions of Pisum fulvum and Pisum elatius were inoculated with $P$. pinodes isolates that had been sampled in various locations from domesticated pea as well as from diverse Pisum fulvum and Pisum elatius populations in Israel. When Pisum sativum plants were inoculated, RAUDPC values ranged from 0.3 to 0.8 but, in most cases the values were around 0.5. Nevertheless, this variation could not be attributed to the original host, i.e., the sampled Pisum species, or to the location of the isolate (Fig. 6A, B, C, D, and G). Similar trends were observed when the challenged hosts were Pisum fulvum (Fig. 6E and $\mathrm{H}$ ) or Pisum elatius (Fig. 6I). It appears that differences in RAUDPC values, if any, represented variability in aggressiveness among specific isolates (irrespective of their origin), combined with variations between experiments.

\section{DISCUSSION}

Ascochyta blight symptoms are common in commercial pea fields in Israel and were found to be widespread in Pisum populations growing in natural ecosystems (D. Shtienberg personal observation). Eighteen fungal isolates originating from symptomatic plant tissues
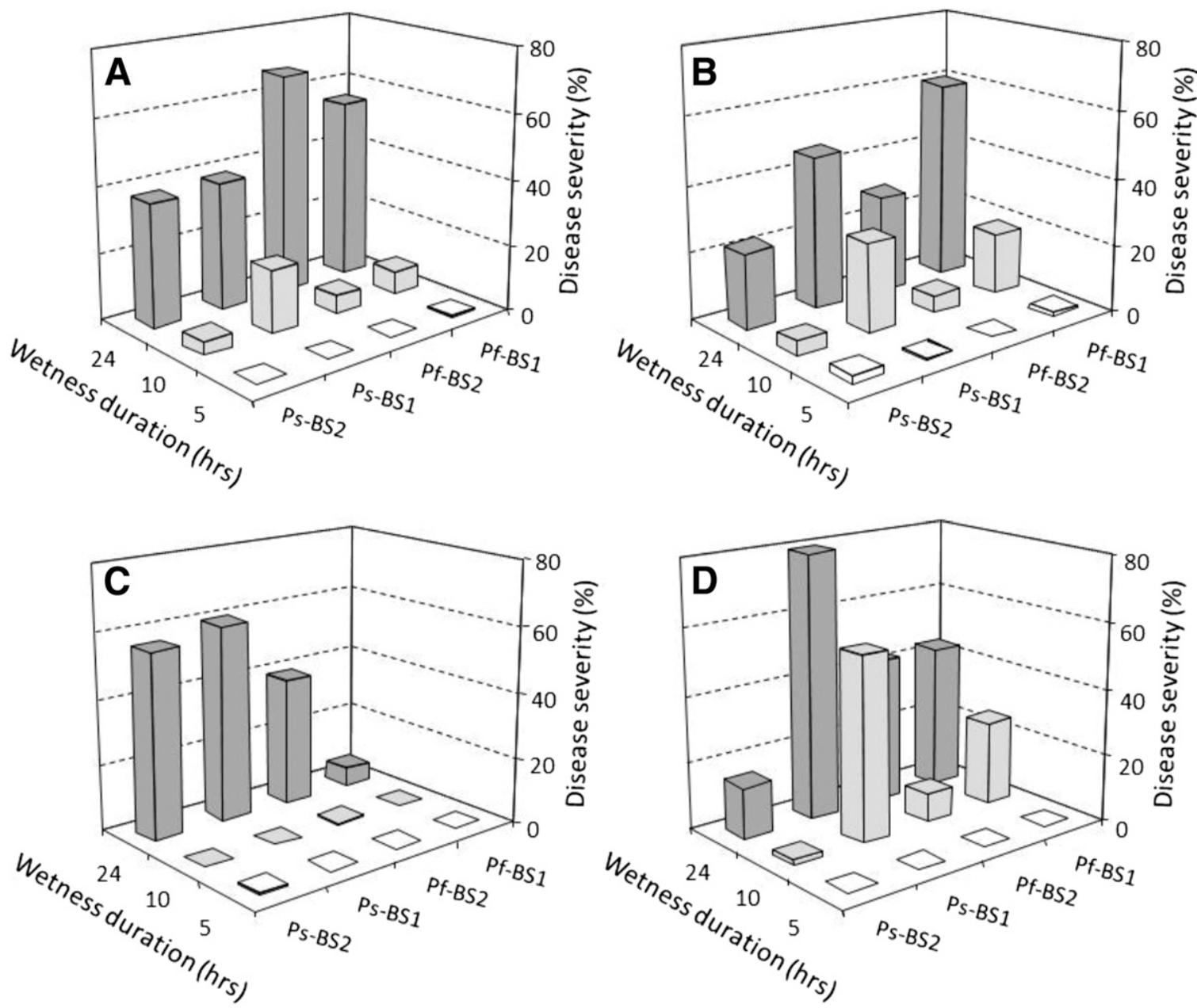

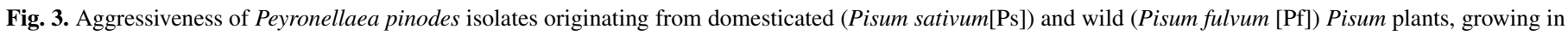

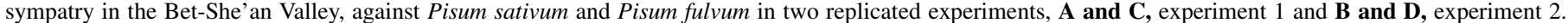
Challenged hosts were Pisum sativum (A and B) and Pisum fulvum (C and D). After inoculation, the plants were kept wet for 5 to 24 h. 
were examined and identified in the current study: three of them were sampled from Pisum sativum, 11 from Pisum fulvum, and four from Pisum elatius, and all were identified as $P$. pinodes. This result was not unexpected; $P$. pinodes is the primary pathogen of the ascochyta complex prevailing worldwide (Bretag et al. 2006; Khan et al. 2013). Furthermore, in this study, we focused on symptoms developing on the upper plant parts, i.e., leaves and upper stems, where $P$. pinodes is likely to be dominant, and not on the collar regions, where the Phoma species are likely to prevail (Bretag et al. 2006) (O. Frenkel unpublished data). Variations in the SNP of rDNA sequences (ITS) and the G3PD (Peever et al. 2007) proved to serve as an effective tool to distinguish among the various fungal genera associated with ascochyta blight symptoms. The diversity of SNPs within $P$. pinodes was very limited, i.e., there was only one SNP, but the minor level of haplotypic difference does not imply that the phenotypic diversity is necessarily limited. In D. rabiei, hardly any SNPs were found within demes from wild and domesticated origins, but wide variations were found in host specialization and temperature adaptation (Frenkel et al. 2010). It is possible that a more extensive sampling strategy across a wider ecogeographic range in Israel would yield a different pattern of SNP variation within the $P$. pinodes. Nevertheless, the present results suggest that the likelihood of finding such varied patterns is rather low.

The $P$. pinodes isolates examined in the present study seemed to be well-adapted to the environmental conditions prevailing in the region in autumn, winter, and spring. Spore germination and mycelial

TABLE 2. $P$ values from the analyses of variance applied to the data recorded in two experiments aimed at determining the aggressiveness of Peyronellaea pinodes isolates originated from domesticated (Pisum sativum) and wild (Pisum fulvum) plants, growing in sympatry in the Bet-She'an Valley, against Pisum sativum and Pisum fulvum ${ }^{\mathrm{a}}$

\begin{tabular}{|c|c|c|c|c|c|}
\hline \multirow[b]{2}{*}{ Source } & \multirow[b]{2}{*}{ df } & \multicolumn{2}{|c|}{$\begin{array}{c}\text { Final } \\
\text { severity }(\%)\end{array}$} & \multicolumn{2}{|c|}{$\begin{array}{l}\text { RAUDPC }^{b} \\
\left(\text { day }^{-1}\right)\end{array}$} \\
\hline & & Exp. 1 & Exp. 2 & Exp. 1 & Exp. 2 \\
\hline Original host plant $(\mathrm{OH})$ & 1 & 0.915 & 0.639 & 0.926 & 0.576 \\
\hline Isolate within host $(\mathrm{I}[\mathrm{OH}])$ & 2 & $<0.001$ & 0.507 & $<0.001$ & 0.107 \\
\hline Challenged host species $(\mathrm{CH})$ & 1 & 0.508 & 0.120 & 0.654 & 0.047 \\
\hline Wetness duration (W) & 2 & $<0.001$ & 0.002 & 0.020 & 0.001 \\
\hline $\mathrm{H} \times \mathrm{IH}$ & 1 & 0.196 & $<0.001$ & 0.188 & $<0.001$ \\
\hline $\mathrm{H} \times \mathrm{W}$ & 2 & 0.476 & 0.724 & 0.609 & 0.782 \\
\hline $\mathrm{I}[\mathrm{OH}] \times \mathrm{CH}$ & 2 & 0.010 & 0.577 & 0.015 & 0.204 \\
\hline$[\mathrm{OH}] \times \mathrm{W}$ & 4 & 0.003 & 0.028 & $<0.001$ & 0.002 \\
\hline $\mathrm{CH} \times \mathrm{W}$ & 2 & 0.583 & 0.348 & 0.775 & 0.005 \\
\hline $\mathrm{CH} \times \mathrm{H} \times \mathrm{W}$ & 2 & 0.276 & $<0.001$ & 0.248 & $<0.001$ \\
\hline $\mathrm{I}[\mathrm{OH}] \times \mathrm{CH} \times \mathrm{W}$ & 4 & 0.116 & 0.599 & 0.014 & 0.651 \\
\hline
\end{tabular}

a After inoculation, the plants were maintained wet for 5 to $24 \mathrm{~h}$. Bold indicates significant effects $(P<0.05)$.

b RAUDPC = relative area under the disease-progress curve. growth took place over a wide range of temperatures: the lower and upper cardinal temperatures being 2 to $9^{\circ} \mathrm{C}$ and 33 to $38^{\circ} \mathrm{C}$, respectively. The optimal temperatures ranged from 22 to $26^{\circ} \mathrm{C}$ (Figs. 1 and 4). These records are comparable with or cover slightly wider ranges (lower and upper cardinal temperatures) and higher levels (optimal temperature) than previous findings for this pathogen: Sattar (1934) reported that the optimal temperature range for germination of spores was 20 to $25^{\circ} \mathrm{C}$, and Lawyer (1984), Roger and Tivoli (1996), and Hare and Walker (1945) reported optimum temperatures of 24,20 , and 20 to $28^{\circ} \mathrm{C}$, respectively, for pycnidial formation in vitro. The optimal temperatures for mortality of seedlings originating from colonized seeds were 15 to $18^{\circ} \mathrm{C}$ (Wallen $1965)$ and that for symptom development on artificially inoculated plants $20^{\circ} \mathrm{C}$ (Bretag 1991; Roger et al. 1999). In the present study, as expected, wetness duration affected development of disease symptoms; at optimal temperature, disease severity was significantly higher on plants maintained under moist conditions for $24 \mathrm{~h}$ postinoculation than on those exposed to $10 \mathrm{~h}$ of wetness. Disease severity on plants maintained under moist conditions for $5 \mathrm{~h}$ was relatively low (Fig. 3 ). Although there were some differences in the magnitude of the effects, these findings corroborate those described previously by Bretag et al. (2006), Roger et al. (1999), and others. It is possible that the differences in responses to temperature and wetness durations of the pathogen observed in the various studies reflect adaptation of the tested isolates to the environmental conditions prevailing at the sites from which they were originating. It is also possible that these differences resulted from differences among the specific experimental procedures and analytical techniques employed by the various experimenters. In the present study, we examined whether the environmental conditions prevailing in the sampling site and the host of origin (domesticated pea or wild Pisum species) affected the temperature response and the aggressiveness of the $P$. pinodes isolates.

Our initial hypothesis was that the temperature response and aggressiveness of the isolates originating from domesticated pea plants would not differ from those originating from wild Pisum species growing in sympatry. This was based on our knowledge that no major shifts in the growing season of pea occurred since domestication. In the natural ecosystems, Pisum seeds germinate in the autumn and the plants grow in the winter and mature in the spring. Pea cropping follows the same time patterns. Indeed, the temperature responses (Fig. 1), spore germination rates (Fig. 2), and aggressiveness (Fig. 3; Table 2) of isolates sampled from domesticated pea plants did not differ from those of isolates sampled from adjacent wild populations. The findings that wetness duration had significant effects on aggressiveness and its involvement in interaction terms, as revealed by the ANOVA tests (Fig. 3; Table 2), highlight the significance of this environmental variable compared with that of the genetic variables, i.e., original host plant, isolate, and
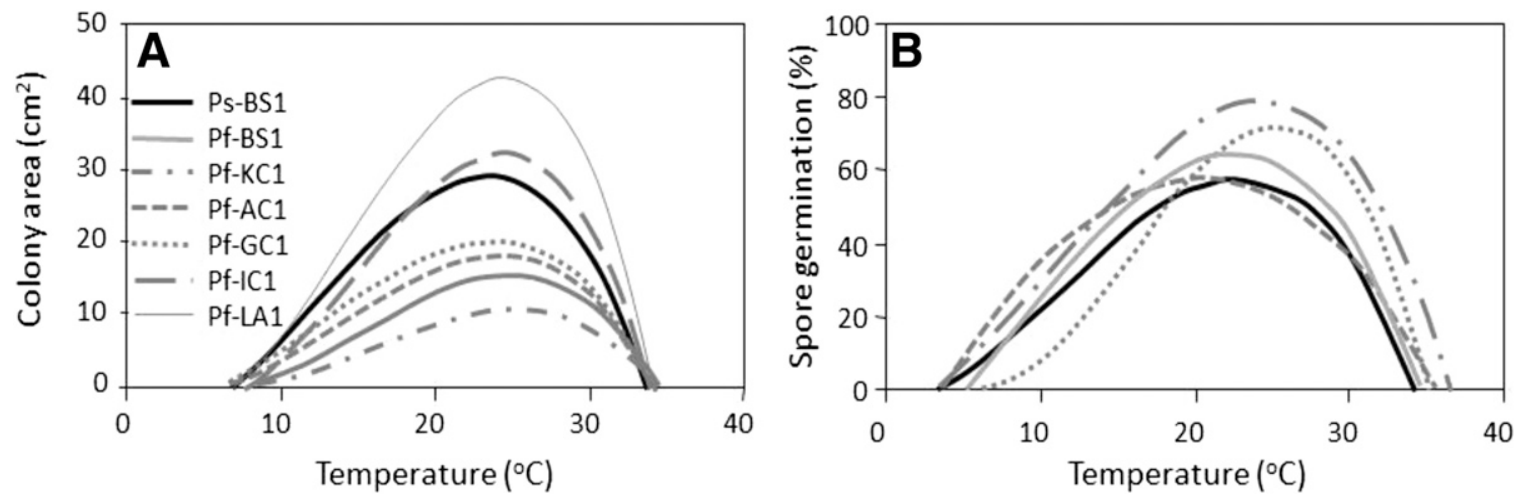

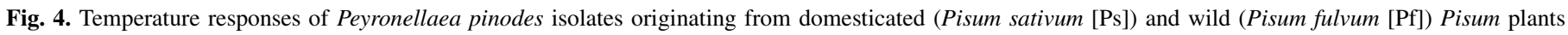

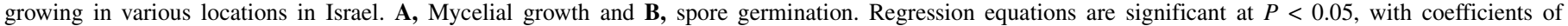
determination $\left(\mathrm{R}^{2}\right)$ ranging from 0.58 to 0.85 . Data points are omitted to avoid crowding of the graphs. 
challenged host species, in determining the severity of the resulting disease. The only apparent exception to this pattern was that of the two isolates obtained from wild Pisum fulvum in the foothills of Mt. Gilboa with a smaller colony area than those of the two isolates sampled in pea crops in the Bet-She' an Valley (Fig. 1A). It should be noted, however, that the two isolates originating from domesticated crops differed from each other as well.

In our experiments, we observed variations in the temperature responses and aggressiveness of some of the tested isolates. For example, variations in temperature response of isolate Ps-BS1 are
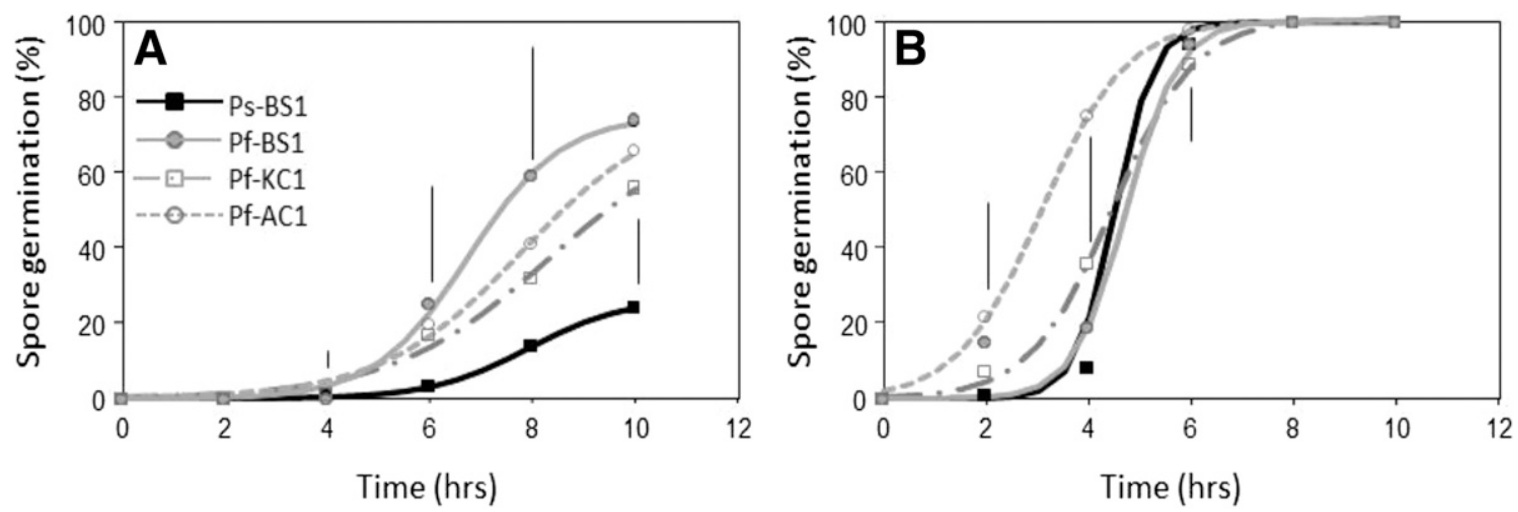

Fig. 5. Spore germination rates of Peyronellaea pinodes isolates originating from domesticated and wild Pisum plants (Pisum sativum [Ps] and Pisum fulvum [Pf], respectively) growing in various locations in Israel at $\mathbf{A}, 10^{\circ} \mathrm{C}$ and $\mathbf{B}, 20^{\circ} \mathrm{C}$. Regression equations are significant at $P \leq 0.001$, with coefficients of determination ranging from 0.98 to 0.99 . Vertical lines represent the least significant difference between germination rates calculated for each temperature, as determined according to Tukey's highly significant difference test at $P<0.05$.
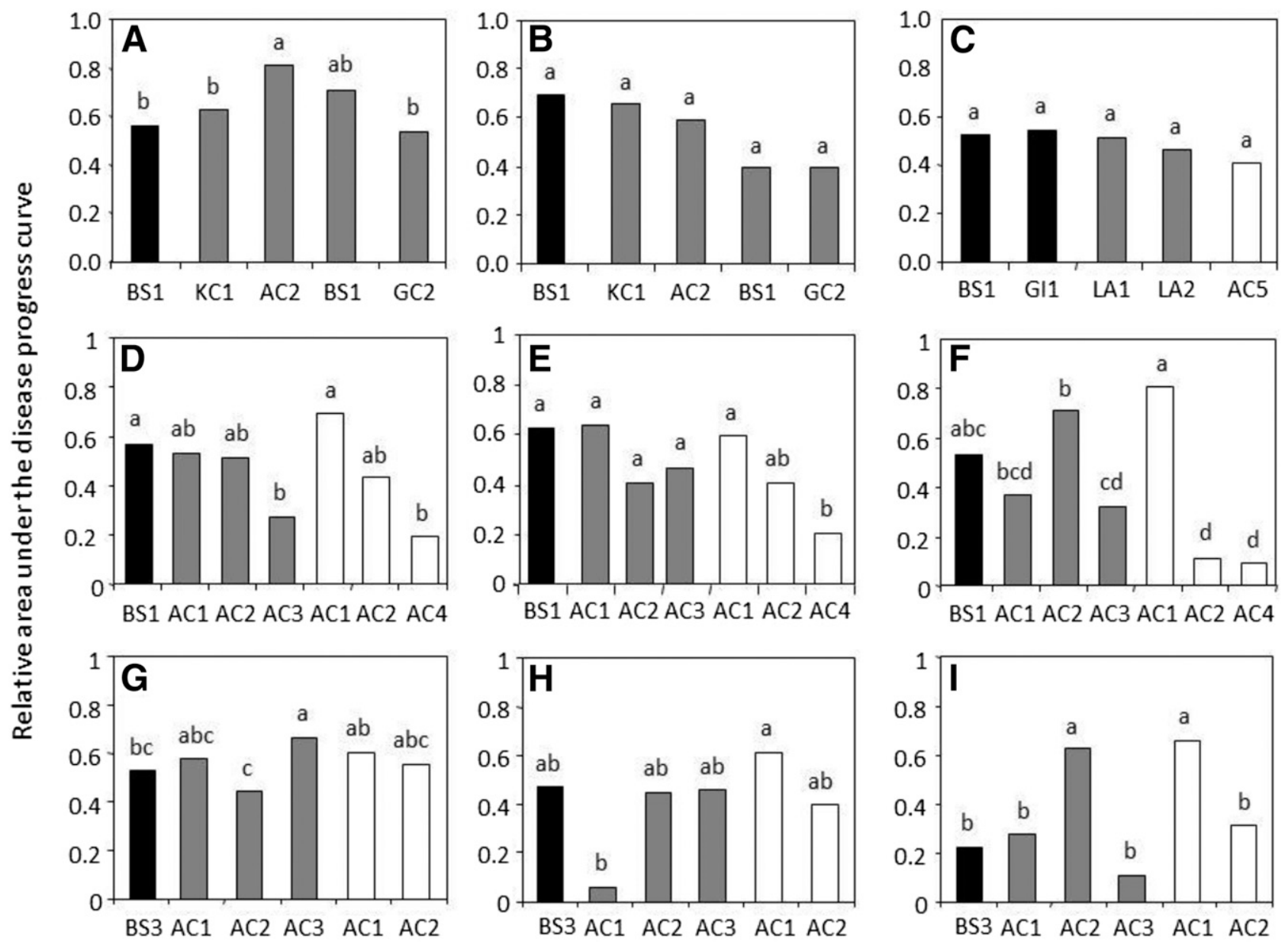

BS1 AC1 AC2 AC3 AC1 AC2 AC4
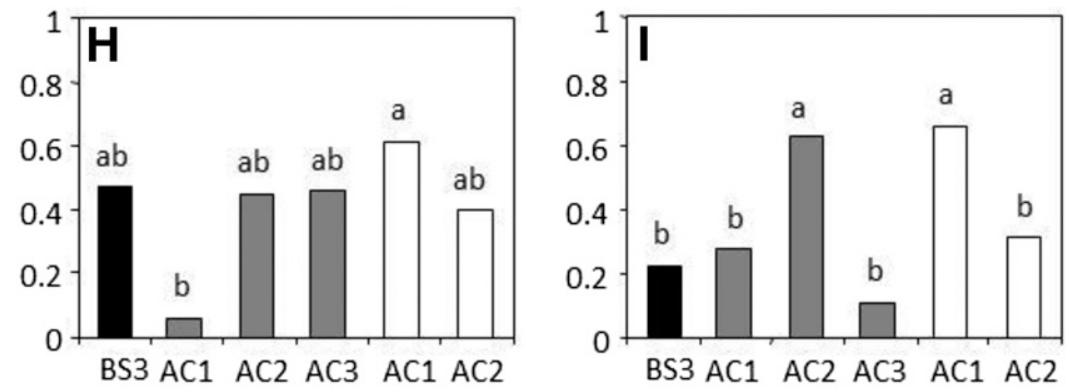

Isolate

Fig. 6. A, B, C, D, and G, Aggressiveness of Peyronellaea pinodes isolates originating from domesticated (Pisum sativum, black bars) and wild (Pisum fulvum, gray bars; Pisum elatius, open bars) Pisum plants, growing in various locations in Israel, against Pisum sativum, $\mathbf{E}$ and $\mathbf{H}$, Pisum fulvum, and $\mathbf{F}$ and $\mathbf{I}$, Pisum elatius in five replicated experiments. A represents experiment 3; B, experiment 4; C, experiment 5; D, E, and F, experiment 6; and G, H, and I, experiment 7. In each graph, values of bars accompanied by different letters differ significantly, as determined by Tukey's highly significant difference test, at $P<0.05$. 
depicted in Figures 2 and 5; the rate of spore germination after $4 \mathrm{~h}$ differed markedly between these experiments. Variation in aggressiveness can be seen in the effects of the various factors included in the ANOVA table (Table 2) and, for example, in the data presented in Figure 6. Differences in RAUDPC values between isolates Pf-AC2 and Ps-BS1 were significant in experiment 3 (Fig. 6A) but not in experiments 4 and 6 (Fig. 6B and D). This variation was observed despite the efforts invested in employing similar procedures in the repeated experiments. Variations in temperature response and aggressiveness were repeatedly reported in the P. pinodes/ Pisum sativum pathosystem but were attributed to the existence of fungal pathotypes (Ahmed et al. 2015; Setti et al. 2011). In our view, the variation observed in our present experiments might be an intrinsic feature of this pathosystem, similar to the variation observed and reported by Lichtenzveig et al. (2002) for the Cicer arietinum/D. rabiei pathosystem.

Our second hypothesis was that the temperature responses and aggressiveness of $P$. pinodes strains isolated from Pisum plants growing in dissimilar ecologies would differ significantly. We presumed that evolutionary forces would result in adaptation of $P$. pinodes populations to the local environmental conditions. This was demonstrated in many pathosystems (Burdon 1987; Harlan 1976), among which was D. rabiei of chickpea (Frenkel et al. 2010; Özkilinc et al. 2010; 2011). To test this hypothesis, we examined $P$. pinodes isolates sampled from areas that differed in prevailing environmental conditions: western Galilee (Kziv and Ga'aton Creeks; annual precipitation of $700 \mathrm{~mm}$ ); western Samaria (I'ron Creek; 600 mm); eastern Galilee (A'mud Creek; 390 mm), southern Judean Foothills (Lakhish; $350 \mathrm{~mm}$ ), and the Bet-She' an Valley and Mt. Gilboa (annual precipitation below $300 \mathrm{~mm}$ ). These varied precipitation patterns are also associated with differences in the respective seasonal temperatures profiles. Interestingly, and contrary to our hypothesis, the temperature responses (Fig. 4), spore germination rates (Fig. 5), and aggressiveness (Fig. 6) of the isolates did not show any association with their regional origin. This implies that there is no ecological divergence within the Israeli $P$. pinodes gene pool. Recently, Le May et al. (2012) examined the temperature adaptation of $P$. pinodes isolates from domesticated pea crops growing in the winter and in the spring in France. Although they could not detect temperature adaptation in the two groups of isolates, they found that isolates from winter pea were more pathogenic than isolates from spring pea on hosts raised under winter conditions, whereas isolates from spring pea were more pathogenic than those from winter pea on plants raised under spring conditions. Le May et al. (2012) concluded that disease developed on winter and spring peas was initiated by a single population of $P$. pinodes, whose pathogenicity is a plastic trait modulated by the physiological status of the host plant.

Our observation of a lack of differences in temperature responses and aggressiveness among isolates originated in regions with diverse conditions and between those originated from domesticated pea or from wild Pisum spp. led us to hypothesize that Israel is inhabited by a single metapopulation of $P$. pinodes. Several lines of evidence support this interpretation.

The first relates to the prevalence of one or more hosts. Occurrence of wild Pisum populations across the Mediterranean district of Israel is rather solid and stable from year to year (Abbo et al. 2013; Ladizinsky and Abbo 2015). Furthermore, artificial inoculation tests revealed that $P$. pinodes is capable of attacking numerous wild legumes other than Pisum spp., i.e., Lathyrus, Vicia, Medicago, Melilotus, Lens, Trifolium, Lupinus, and Cicer species (Bretag et al. 2006). Field crops, such as fenugreek (Trigonella foenum-graecum) and vetch (Vicia spp.), and ornamentals, such as sweet pea (Lathyrus odoratus L.), also are affected by this pathogen (Bretag et al. 2006; Fondevilla et al. 2005; Habibi et al. 2016; Le May et al. 2014). These plant species prevail in natural ecosystems, and conspecific domesticates in cultivated fields and gardens across Israel may serve as primary and secondary hosts for the pathogen.
The second line of evidence relates to the epidemiology of the pathogen. Unlike most of the other ascochyta pathogens, the predominant stage in the life cycle of $P$. pinodes is the teleomorph. Ascospores released from pseudothecia produced on infected plant debris serve as the main source of primary inoculum. Pseudothecia also are formed on diseased, senescent host tissues, and ascospores are released throughout the season and constitute an important secondary source of inoculum (Bretag et al. 2006; Khan et al. 2013; Salam et al. 2011; Tivoli and Banniza 2007). Whereas picnidiospores, which are the main source of secondary inoculum of the other ascochyta pathogens, are dispersed to distances of only a few centimeters (Roger and Tivoli 1996), dispersal of $P$. pinodes ascospores potentially extends beyond $1.6 \mathrm{~km}$ (Schoeny et al. 2007). In a parallel study, it was demonstrated that ascochyta blight infections are very common in populations of Pisum elatius in Israel and that disease severity was not related to rain quantity (Golani et al. 2016). Furthermore, it was found that diseased plants were spatially distributed at random, whereas Pisum elatius plants tended to grow in patches. Based on these observations, it was concluded that airborne ascospores rather than picnidiospores were the principal fungal propagules. The single-metapopulation presumption is supported by Peever et al. (2007), who studied the evolutionary relationships among a worldwide sample of ascochyta fungi from wild and domesticated legume hosts. Peever et al. (2007) carried out phylogenetic analyses of DNA sequences from the ribosomal ITS regions and, also, from portions of three proteincoding genes, G3PD, translation elongation factor 1-alpha, and chitin synthase 1. They found that isolates from Pisum elatius clustered with isolates from domesticated pea, and they pointed out that this finding was consistent with the hypothesis that the source of ascochyta blight epidemics on pea crops might be ascochytainfected Pisum elatius (Peever et al. 2007).

Susceptible hosts prevail in natural ecosystems and cultivated fields across Israel, where climatic conditions that occur in the autumn, winter, and spring are generally conducive for pathogen development. As host specificity among Pisum species was not observed in the present study and because $P$. pinodes inoculum can be dispersed over long distances, it seems possible that the pathogen has formed a single metapopulation across Israel. It should be noted that this assumption is based on a relatively small sample that should be expanded before reaching a definite conclusion. Furthermore, a wider screening of DNA markers of Israeli $P$. pinodes isolates might corroborate or refute the observation concerning the apparent single metapopulation of $P$. pinodes that parasitizes domesticated pea fields and wild Pisum spp. across Israel.

\section{ACKNOWLEDGMENTS}

This study was supported by the Chief Scientist of Israel's Ministry of Agriculture and Rural Development. S. Abbo is the incumbent of the Jacob and Rachel Liss Chair in Agronomy in the Hebrew University of Jerusalem, Rehovot. Contribution number 554/15 from ARO, the Volcani Center, POB 6, Bet-Dagan 50250, Israel.

\section{LITERATURE CITED}

Abbo, S., Frenkel, O., Sherman, A., and Shtienberg, D. 2007. The sympatric Ascochyta pathosystems of Near Eastern legumes, a key for better understanding of pathogen biology. Eur. J. Plant Pathol. 119:111-118.

Abbo, S., Shtienberg, D., Lichtenzveig, J., Lev-Yadun, S., and Gopher, A. 2003. The chickpea, summer cropping, and a new model for pulse domestication in the ancient Near East. Q. Rev. Biol. 78:435-448.

Abbo, S., Zezak, I., Schwartz, E., Lev-Yadun, S., and Gopher, A. 2008. Experimental harvest of wild pea in Israel: Implications for the origin of Near Eastern farming. J. Archaeol. Sci. 35:922-929.

Abbo, S., Zezak, I., Zehavi, Y., Schwartz, E., Lev-Yadun, S., and Gopher, A. 2013. Six seasons of wild pea harvest in Israel: Bearing on Near Eastern plant domestication. J. Archaeol. Sci. 40:2095-2100.

Ahmed, H., Chang, K. F., Hwang, S. F., Fu, H., Qixing Zhou, Q., Strelkov, S., Conner, R., and Gossen, B. 2015. Morphological characterization of fungi 
associated with the ascochyta blight complex and pathogenic variability of Mycosphaerella pinodes on field pea crops in central Alberta. Crop J. 3:10-18. Aveskamp, M. M., de Gruyter, J. and Crous, P. W. 2008. Biology and recent developments in the systematics of Phoma, a complex genus of major quarantine significance. Fung. Divers. 31:1-18.

Aveskamp, M. M., de Gruyter, J., Woudenberg, J. H. C., Verkley, G. J. M., and Crous, P. W. 2010. Highlights of the Didymellaceae: A polyphasic approach to characterize Phoma and related pleosporalean genera. Stud. Mycol. 65:1-60.

Ben-Ze'ev, N., and Zohary, D. 1973. Species relationships in the genus Pisum L. Israel J. Bot. 22:73-91

Berbee, M. L., Pirseyedi, M., and Hubbard, S. 1999. Cochliobolus phylogenetics and the origin of known, highly virulent pathogens, inferred from ITS and glyceraldehyde-3-phosphate dehydrogenase gene sequences. Mycologia 91:964-977.

Bretag, T. 1991. Epidemiology and control of ascochyta blight of field peas. Ph.D. thesis. La Trobe University, Victoria, Australia.

Bretag, T. W., Keane, P. J., and Price, T. V. 2006. The epidemiology and control of ascochyta blight in field peas: A review. Aust. J. Agric. Res. 57: 883-902.

Burdon, J. J. 1987. Disease and Plant Population Biology. Cambridge University, Cambridge, UK.

Chilvers, M. I., Rogers, J. D., Dugan, F. M., Stewart, J. E., Chen, W., and Peever, T. L. 2009. Didymella pisi sp. nov., the teleomorph of Ascochyta pisi. Mycol. Res. 113:391-400.

Davidson, J. A., Hartley, D., Priest, M., Krysinska-Kaczmarek, H., McKay, A., and Scott, E. S. 2009. A new species of Phoma causes ascochyta blight symptoms on field peas (Pisum sativum) in South Australia. Mycologia 101:120-128.

Dinoor, A. 1974. Role of wild and cultivated plants in the epidemiology of plant diseases in Israel. Annu. Rev. Phytopathol. 12:413-436.

Fatehi, J., Bridge, P. D., and Punithalingam, E. 2003. Molecular relatedness within the "Ascochyta pinodes-complex". Mycopathologia 156:317-327.

Fondevilla, S., Avila, C. M., Cubero, J. L., and Rubiales, D. 2005. Response to Mycosphaerella pinodes in a germplasm collection of Pisum spp. Plant Breed. 124:313-315.

Frenkel, O., Peever, T. L., Chilvers, M. I., Ozkilinc, H., Can, C., Abbo, S., Shtienberg, D., and Sherman, A. 2010. Ecological genetic divergence of the fungal pathogen Didymella rabiei on sympatric wild and domesticated Cicer spp. Appl. Environ. Microbiol. 76:30-39.

Frenkel, O., Sherman, A., Abbo, S., and Shtienberg, D. 2008. Different ecological affinities and aggressiveness patterns among Didymella rabiei isolates from sympatric domesticated chickpea and wild Cicer judaicum. Phytopathology 98:600-608.

Gladieux, P., Guerin, F., Giraud, T., Caffier, V., Lemaire, C., Parisi, L., Didelot, F., and Le Cam, B. 2011. Emergence of novel fungal pathogens by ecological speciation: Importance of the reduced viability of immigrants. Mol. Ecol. 20:4521-4532.

Golani, M., Frenkel, O., Borenstein, M., Shulhani, R., Abbo, S., and Shtienberg, D. 2016. Prevalence, development, and significance of Ascochyta blight caused by Peyronallaea pinodes in Pisum elatius populations growing in natural ecosystems. Phytopathology 106:833-841.

Habibi, A., Peever, T. L., Banniza, S., and Morall, R. A. A. 2016. First report of ascochyta blight of fenugreek (Trigonella foenum-graecum) caused by Peyronellaea pinodes in Canada. Plant Dis. 100:520.

Hare, W. W., and Walker, J. C. 1945. Ascochyta diseases of canning pea. Wisc. Res. Bull. 150:1-8.

Harlan, J. R. 1976. Disease as a factor in plant evolution. Annu. Rev. Phytopathol. 14:31-51.

Jones, L. K. 1927. Studies on the nature and control of blight, leaf and pod spot, and foot-rot of peas caused by species of Ascochyta. NY State Agric. Exp. Sta. Res. Rep. 547:1-46.

Kaiser, W., Muehlbauer, F. J., Hannan, R. M., and Mihov, M. 1998. First report of natural infection of Pisum sativum subsp. elatius by Mycosphaerella pinodes in Bulgaria. Plant Dis. 82:830.

Khan, T. N., Timmermann-Vaughan, T. M., Rubiales, D., Warkentin, T. D., Siddique, K. H. M., Erskine, W., and Barbetti, M. J. 2013. Didymella pinodes and its management in field pea: Challenges and opportunities. Field Crops Res. 148:61-77.

Ladizinsky, G., and Abbo, S. 2015. The Search for Wild Relatives of Cool Season Legumes. Springer Briefs in Plant Science. Springer, Heidelberg.

Lawyer, A. S. 1984. Diseases caused by Ascochyta spp. Pages 11-15 in: Compendium of Pea Diseases. D. J. Hagedorn. APS Press, St Paul, MN, U.S.A..
Le May, C., Guibert, M., Baranger, A., and Tivoli, B. 2014. A wide range of cultivated legume species act as alternative hosts for the pea aschochyta blight fungus, Didymella pinodes. Plant Pathol. 63:877-887.

Le May, C., Guibert, M., Leclerc, A., Andrivon, D., and Tivoli, B. 2012. A single, plastic population of Mycosphaerella pinodes causes ascochyta blight on winter and spring pea (Pisum sativum) in France. Appl. Environ. Microbiol. 78:8431-8440.

Leppik, E. E. 1970. Gene centers of plants as sources of disease resistance. Annu. Rev. Phytopathol. 8:323-344.

Leroy, T., Le-Cam, B., and Lemaire, C. 2014. When virulence originates from non-agricultural hosts: New insights into plant breeding. Infect. Genet. Evol. 27:521-529.

Lichtenzveig, J., Shtienberg, D., Zhang, H. B., Bonfil, D. J., and Abbo, S. 2002. Biometric analyses of the inheritance of resistance to Didymella rabiei in chickpea. Phytopathology 92:417-423.

Onfroy, C., Tivoli, B., Corbière, R., and Bouznad, Z. 1999. Cultural, molecular and pathogenic variability of Mycosphaerella pinodes and Phoma medicaginis var. pinodella isolates from dried pea (Pisum sativum) in France. Plant Pathol. 48:218-229.

Özkilinc, H., Frenkel, O., Abbo, S., Eshed, R., Sherman, A., Ophir, R., Shtienberg, D., and Can, C. 2010. A comparative study of Turkish and Israeli populations of Didymella rabiei, the ascochyta blight pathogen of chickpea. Plant Pathol. 59:492-503.

Özkilinc, H., Frenkel, O., Shtienberg, D., Abbo, S., Sherman, A., Kahraman, A., and Can, C. 2011. Aggressiveness of eight Didymella rabiei isolates from domesticated and wild chickpea native to Turkey and Israel, a case study. Eur. J. Plant Pathol. 131:529-537.

Peever, T. L., Barve, M. P., Stone, L. J., and Kaiser, W. J. 2007. Evolutionary relationships among Ascochyta species infecting wild and cultivated hosts in the legume tribes Cicereae and Vicieae. Mycologia 99:59-77.

Roger, C., and Tivoli, B. 1996. Effect of culture medium, light and temperature on sexual and asexual reproduction of four strains of $M$. pinodes. Mycol. Res. 100:304-306.

Roger, C., Tivoli, B., and Huber, L. 1999. Effects of temperature and moisture on disease and fruit body development of Mycosphaerella pinodes on pea (Pisum sativum). Plant Pathol. 48:1-9.

Salam, M. U., Galloway, J., Diggle, A. J., MacLeod, W. J., and Maling, T. 2011. Predicting regional-scale spread of ascospores of Didymella pinodes causing ascochyta blight disease on field pea. Australas. Plant Pathol. 40: 640-647.

Sattar, A. 1934. A comparative study of the fungi associated with blight diseases of certain cultivated leguminous plants. Trans. Br. Mycol. Soc. 18:276-301.

Schoeny, A., Jumel, S., Rouault, S., Le May, C., and Tivoli, B. 2007. Assessment of airborne primary inoculum availability and modelling of disease onset of ascochyta blight in field peas. Eur. J. Plant Pathol. 119:87-97.

Setti, B., Bencheikh, M., Henni, J., and Neema, C. 2011. Morphological and virulence variation among isolates of Mycosphaerella pinodes the causal agent of pea leaf blight. Afr. J. Agric. Res. 6:1067-1075.

Shaner, G., and Finney, R. E. 1977. The effect of nitrogen fertilization on the expression of slow-mildewing resistance in Knox wheat. Phytopathology 67:1051-1056.

Skoglund, L. G., Harveson, R. M., Chen, W., Dugan, F., Schwartz, H. F., Markell, S. G., Porter, L., Burrows, M. L., and Goswami, R. 2011. Ascochyta blight of peas. Online. Plant Health Prog. doi:10.1094/PHP-20110330-01-RS

Stukenbrock, E. H., and McDonald, B. A. 2008. The evolutionary emergence of plant pathogens in agroecosystems. Annu. Rev. Phytopathol. 46:75-100.

Tivoli, B., and Banniza, S. 2007. Comparison of the epidemiology of ascochyta blights on grain legumes. Eur. J. Plant Pathol. 119:59-76.

Wallen, V. R. 1965. Field evaluation and importance of the ascochyta complex on peas. Can. J. Plant Sci. 45:27-33.

Warkentin, T. D., Smýkal, P., Coyne, C. J., Weeden, N., Domoney, C., Bing, D.-J., Leonforte, A., Xuxiao, Z., Dixit, G. P., Boros, L., McPhee, K. E., McGee, R. J., Burstin, J., and Ellis, T. H. N. 2015. Pea. Pages 37-83 in: Grain Legumes, Handbook of Plant Breeding, Vol. 10. A. M. De Ron, ed. Springer, New York.

White, T. J., Burns, T., Lee, S., and Taylor, J. 1990. Amplication and direct sequencing of fungal ribosomal RNA genes for phylogenetics. Pages 315-322 in: PCR Protocols, A Guide to Methods and Applications. M. A. Innis, D. H. Gelfand, J. J. Sninsky, and T. J. White, eds. Academic Press, San Diego, CA.

Xue, A. G., and Warkentin, T. W. 2001. Partial resistance to Mycosphaerella pinodes in field pea. Can. J. Plant Sci. 81:535-540. 